\title{
Reconstruction surgery for dislocated hips in children with cerebral palsy
}

\author{
D.A. Popkov ${ }^{1}$, G.M. Chibirov ${ }^{1}$, A.D. Tomov ${ }^{2}$
}

${ }^{1}$ Ilizarov National Medical Research Centre for Traumatology and Orthopedics, Kurgan, Russian Federation

${ }^{2}$ Morozov Children's City Clinical Hospital of the Moscow City Health Department, Moscow, Russian Federation

\begin{abstract}
Introduction The article is a literature review focusing on reconstruction surgery for dislocated hips in children with cerebral palsy (CP). Material and methods Publications in Scopus, PubMed, RSCI indexed journals over the past 20 years were reviewed for hip dislocation in children with CP. Results and discussion The article discusses the prevalence of the orthopaedic complication of cerebral palsy, pathogenesis, diagnosis, indications to surgery, choice of surgical technique, early rehabilitation and long-term outcomes. A report made for the first educational meeting of the European Pediatric Orthopaedic Society held in Russia at the Ilizarov Center in 2021 was used for the contribution. Conclusion Surgical treatment is indicated for hip dislocation in children with CP using holistic approach and principles of single-event multilevel surgery that suggest hip reconstruction, addressing contractures and deformities of the subjacent segments and creating conditions for postoperative postural management. Standardized indications, patient selection and optimal time for intervention are to be carefully considered for the procedure with the use of customized orthopaedic implants and techniques.
\end{abstract}

Keywords: cerebral palsy, hip dislocation, hip reconstruction, multilevel surgery

Cerebral palsy $(\mathrm{CP})$ is the most common cause of motor disorders that appear in early childhood and is a lifelong condition occurring in approximately 1 in 500 liveborn infants. Around the world, more than 17 million people are living with this disability [1]. Hip dislocation in CP patients is the most severe orthopaedic complication that affects the child's quality of life, the family and caregivers [2-4]. Hip dislocation can result in asymmetric posture, serious difficulties with postural management, difficulties with personal hygiene, pain with hip mobilization and a risk of early onset scoliosis [4-8].

The incidence of hip displacement in CP patients

An overall incidence of hip displacement for the entire birth cohort reported is $\leq 35 \%$ [2], and it shows a linear relationship with the level of gross motor function graded according to the Gross Motor Function Classification System (GMFCS) [9]. The incidence of hip subluxation (Reimers migration index 30-33\%) [10] was shown to increase with the increase in the GMFCS level in the study groups of children and was reported to develop in $41 \%$ [2], $46 \%$ [11], $50 \%$ [12], $39 \%$ [13] of patients GMFCS level III; in $69 \%$ [2], $59 \%$ [11], $62 \%$ [12], $45 \%$ [13] of patients GMFCS level IV; in $90 \%$ [2], $76 \%$ [11], $68 \%$ [12], $72 \%$ [13] of patients GMFCS level V.

\section{Pathogenesis of hip dislocation in CP patients}

At birth, the hip joints appear to develop according to the gestational age in children who later develop cerebral palsy, similar to children without neurological disorders [14]. Abnormal forces created by hip adductor muscles (primarily $\mathrm{m}$. adductor longus), followed by the influence of the $\mathrm{m}$. gracilis and m.iliopsoas combined with excessive femoral anteversion and coxa valga and reduced weight-bearing been suggested as the etiology of hip subluxation and dislocation in children with CP [15-20]. The reduced activity of the gluteal muscles results in persistent excessive femoral anteversion [21]. With no treatment performed, the risk of hip dislocation is highest before seven years of age [22, 23]. Terjesen [13] reported that the majority of hip subluxations had already occurred before the age of 5 years at a mean age of 4 years 5 months with $81 \%$ in children with GMFCS levels IV or V.

The annual migration percentage progression of $4 \%$ reported by Terjesen [13], 6-7\% reported by Soo et al. [2] and Connelly et al. [11], 7-9 \% [24] are considered unfavorable and are accompanied by hip subluxation. Hip subluxation is considered the onset of an orthopaedic complication [5] with the migration index (Reimers index) 30-33\% [5, 12, 25]. Secondary acetabular dysplasia localized posterolaterally or laterally is caused by the head pressing against the acetabular edge in a pathologically forced posture with adducted and flexed hip due to retraction and spasticity of the adductor muscles and the iliopsoas [2, 3, 18, 26-28]. Total acetabular dysplasia normally develops with hip dislocation [24, 28-30].

A severe deformity of the acetabulum and the head develops with a wide area of lost articular cartilage and a bone defect of the head on the lateral and superiorlateral aspects of the femoral head in untreated children at 10 years $[6,14,19,31]$ with severe pain and no posibility for hip reconstruction [30, 32-34]. 
The incidence of severe pain in older children with subluxations and dislocations of the hip is 50 $73.7 \%[6,33,35]$. Postural management, passive vertical posture with an axial symmetrical loading on the lower limbs facilitate formation and development of the hip joint, prevention of hip dislocation [36, 37]. Passive vertical posture is useful for the functioning of internal organs improving the involvement and socialization of the patient [38-41]. The axial loading on the limbs reduces the risks of pathological osteoporosis related fractures up to 4-fold [42]. Passive verticalization cannot be provided for children GMFCS levels IV-V due to contractures or dislocations of the hip joint, flexion contractures of the knee joint and severe feet deformities [43-45]. Postural problems with dislocated hip are also recognized as the cause of secondary pathological conditions including additional loss of motor capacity, greater need for assistance, cardiovascular and respiratory disorders, secondary osteoporosis and a risk of pathological fractures, trophic disorders of soft tissues due to unchanging posture [42, 46-48].

The impact of hip dislocation on the quality of life

Hip surveillance programs were initiated for children with severe $\mathrm{CP}$ for identifying and monitoring the critical early indicators of progressive hip displacement from the first year of life [16, 49]. The programs allowed for early postural management and correction, verticalization with an axial load on the limbs, botulinum therapy, adequate bracing and surgical intervention on soft tissues [5, 16, 25, 49-51].

The frequency of anteroposterior pelvis radiography for severe $\mathrm{CP}$ cases would be dependent on the progression of the migration percentage measurements, GMFCS level and hip surveillance program and is normally performed once every 6 to 12 months $[5,16,25,49]$. Radiographic examination is indicated for a child who cannot takemore than 10 steps at the age of 30 months, for adduction contracture of the hip joints, asymmetric abduction or pronounced spasticity at the age of $12-18$ months $[13,25]$. The Reimers migration index, the acetabular index and the Wiberg's lateral center edge angle are important radiological hip parameters for diagnostic purposes and for evaluating the effectiveness of conservative and surgical treatment $[10,22,52,53]$. Surveillance program based on radiographic imaging of the hips demonstrated the ability to reduce the amount of reconstructive surgery to be performed prior to the development of acetabular dysplasia and rule out palliative surgery [16, 49, 54].

\section{Surgical orthopaedic treatment}

The goals of hip dislocation correction in children with $\mathrm{CP}$ are to improve quality of life, prevent early coxarthrosis, relieve pain, improve conditions for mobility, ambulation, care, comfortable sitting posture and reduce dependence on others [55]. Preventive surgery including soft tissue procedures of lengthening the adductor muscles, iliopsoas, knee flexor muscles can be indicated for children with the migration percentage of $30-50 \%$ [25] or less than $40 \%$ [14]. However, the procedure was shown to be ineffective with reoperation rate of $60-74 \%$ after early soft tissue procedures $[56,57]$.

Reconstruction of the proximal femur necessitates femoral derotational varization osteotomy in combination with or without acetabuloplasty and lengthening of adductors, lengthening (GMFCS III) or excision (GMFCS IV-V) of the iliopsoas muscles [52, 58-60]. A Reimers migration percentage greater than $40 \%$, the annual increase by $7 \%$ or greater are the threshold values for a decision to perform reconstructive surgery $[5,22,25]$. The optimal age is considered to be 5-7 years, when the of residual growth period is sufficient for the anatomical formation of the hip joint $[5,55,61,62]$. However, Tomov A.D. et al. [63, 64] and Park H. et al. [65] reported no correlations between the surgeries performed at the age of 8-9 years and less favorable outcomes.

Indications for dysplasia with an acetabular index of less than $30^{\circ}$ remain contraversial. Hagglund et al. $[16,22]$ reported the spontaneous decrease at the baseline acetabular index of less than $30^{\circ}$ during residual growth with lateralization of the femoral head addressed in $29 \%$ of cases with intensive conservative treatment. McNerney et al. [58] reported indications for acetabuloplasty with an acetabular index of $25^{\circ}$ and greater. Cornell et al. [14] reported poor outcomes in 13 out of 15 cases with a baseline acetabular index of $27^{\circ}$ and surgical intervention without correction of acetabular dysplasia.

Acetabuloplasty (Dega, San Diego, Pemberton) is the method of choice for the reconstruction of the pelvic component of the joint $[26,52,58,59,66]$ providing changes in the acetabular volume and the slope of the articular surface. Biomechanical considerations were shown to facilitate surgical creation of the largest deviation of the posterolateral or lateral aspect of the acetabulum in most spastic $\mathrm{CP}$ cases with secondary dysplasia being most pronounced and the femoral head being least covered after varus osteotomy [6668]. Acetabuloplasty according to San Diego can meet the criteria to a greater extent and to a lesser extent with Dega procedure, and there are less indications for Pemberton acetabuloplasty [18, 44, 52, 61, 69]. A "Method for determining the optimal amount and topography of acetabulum dysplasia correction during acetabuloplasty" was offered to idenytify the topography and the amount of acetabular dysplasia correction required (Application for invention No. 201822180, priority of 15.06.2018) [70]. The method employed CT scans of the hip joints in order to 
determine the acetabular index in the frontal plane and the angle of inclination of the acetabulum in the sagittal plane. The amount of acetabular dysplasia correction required could be determined with anatomical angle measurements available to produce acetabuloplasty at the level of the most susceptible edge [63]. Salter osteotomy or triple pelvic osteotomy allows for greater opening of the posterior aspect of acetabulum and are contraindicated in the vast majority of spastic CP cases [14, 26, 58, 65, 69-71].

Bone plates with angular stability made of titanium alloy are considered to be the most reliable bone fixation for osteoporotic bone $[53,72]$ with a lower risk of secondary dislocations and good conditions for early weight-bearing with no need to immobilize the pelvis [52]. The use of blade plates requires extensive use of plaster casts and is often accompanied by complications associated with unstable fixation of osteoporotic bone in up to $4.5 \%[73,74]$.

Development of hip joints in the long-term period after surgery

McNerney et al. [58], Reidy K. et al. [52] reported changes in the migration percentage from $63.6-66 \%$ at the baseline to $2.7-5 \%$ after the intervention with a slight increase to $9.7-11 \%$ at a long term. Tomov A.D. et al. reported the postoperative migration percentage of $0.4-2.0 \%$ with $57.6-72.3 \%$ at the baseline followed by an annual increase of no greater than $3 \%$ with derotational varus osteotomy (DVO) and no greater than $2 \%$ with a combined DVO and acetabuloplasty [64].

An increase in the neck-to-shaft angle (NSA) is reported at a long term period [52, 59, 75]. Miller [18] recommended creating a NSA of $100^{\circ}$ in unambulated patients, and $120^{\circ}$ in ambulated patients. Mazur et al. [75] recommended a NSA of $100-110^{\circ}$ in GMFCS IV-V patients aged $4-12$ years, assuming a $20^{\circ}$ spontaneous increase in NSA during subsequent growth, and a NSA of a $110-120^{\circ}$ in older patients with nearly completed spontaneous growth. Tomov A.D. et al. reported the annual increase in the NSA of not greater than $1-2^{\circ}$ [64].

Recurrent hip subluxations and dislocations can occur as complications of reconstructive interventions with the incidence ranging from 4.1 to $27.9 \%$ [52, 76, 82]. Jozwiak et al. [59] reported 1 dislocation and 6 subluxations (23\%) after 30 reconstructive surgeries at a long term. Rutz et al. [77] reported 2 recurrent hip dislocations at a long term following 168 interventions. McNerney et al. [58] reported 6 hip joints with a migration percentage of greater than $33 \%$ among 61 hips at a long term. The authors attribute all cases of recurrent subluxation to surgery related events including failure to achieve muscle balance. Tomov A.D. et al. reported an annual increase in the Reimers index of $10 \%$ and greater in 3 patients out of 124 due to the absence of postural management and verticalization in the postoperative period that required a serious change in the rehabilitation program and surgical intervention to restore muscle balance $(\mathrm{n}=2)$ and reoperation $(\mathrm{n}=1)[63,64]$.

The mean annual increase in the migration index of $2-3.5 \%$ after reconstructive interventions can demostrate the favorable development of the hip joint and serve as prognostic factor for a good outcome $[64,78]$. An annual increase in the migration index of $7 \%$ or greater is considered unfavorable and is associated with a risk of redislocation [52, 64]. In addition to the successful hip reconstruction, the overall success of treatment largely relies on maintaining conditions for the favorable development of the hip joint including postural management, verticalization, passive and active mobilization of joints, rational orthosis facilitating to the potential of residual growth and remodeling of the articular ends of the hip.

Flexion contractures of the knee and ankle joints and feet deformities are thought to be addressed simultaneously with hip dislocation to ensure favorable conditions for postoperative rehabilitation, early adequate verticalization and ease of using orthotic products [79]. No recurrent hip subluxations/ dislocations were reported in patients who underwent procedures performed according to the principles of multi-level one-event orthopaedic interventions providing muscle balance and a proper long-term postoperative management $[58,64,80,81]$.

Strategy for bilateral and unilateral hip dislocation

Either a sequential correction of the hip dislocation with a short interval of 3 to 6 weeks or simultaneous intervention on both joints can be indicated for bilateral involvement $[52,58,59,82]$. An approach to unilateral hip dislocation includes DVO and intervention on the involved muscle groups only on the side of dislocation $[83,84]$ with subluxation observed on the contralateral limb in $11.8-44.4 \%$ of cases at a long term after reconstruction of the opposiing joint [64, 85, 86]. A more balanced approach is to perform reconstructive intervention on the displaced hip only with the bilateral muscle balance restored supported by healthcare programme for children with $\mathrm{CP}$ including adequate postural management [79, 87, 88].

\section{Evaluation of outcomes}

In addition to orthopaedic and radiological grading systems outcomes were evaluated with pain intensity, symmetry of posture, ease and care scales [62,89]. Pain was fully relieved in $82-100 \%$ of cases at a long term [52, 82, 90]. Krebs et al. [55] reported sitting symmetry with no changes in $77 \%$ of cases, improvements in $14 \%$ and deteriorations in $9 \%$. An improvement in lying symmetry was observed in 
$35 \%$ of the patients, and an improvement in sitting symmetry was observed in $43 \%$ of cases. Outcomes are recommended to be evaluated no earlier than 1 year after the intervention. Stasikelis et al. [91] reported the return of preoperative passive and active ambulation levels at a mean of 7 to 10 months after osteotomy. Multi-level interventions including reconstructive hip surgery performed for children with severe CP facilitate improved quality of life, physical and psychosocial functioning. However, an improved motor activity can occur in patients GMFCS IV only with improved technical means of rehabilitation, and walking can become the main way of ambulation in patients GMFCS III only [63].

Surgical treatment is indicated for hip dislocation in children with CP using holistic approach and principles of single-event multilevel surgery that suggest hip reconstruction, addressing contractures and deformities of the subjacent segments and creating conditions for postoperative postural management. Standardized indications, patient selection and optimal time for intervention are to be carefully considered for the procedure with the use of customized orthopaedic implants and techniques.

\section{REFERENCES}

1. Graham H.K., Rosenbaum P., Paneth N., Dan B., Lin J.P., Damiano D.L., Becher J.G., Gaebler-Spira D., Colver A., Reddihough D.S., Crompton K.E., Lieber R.L. Cerebral palsy. Nat. Rev. Dis. Primers, 2016, vol. 2, article no. 15082. DOI: 10.1038/nrdp.2015.82.

2. Soo B., Howard J.J., Boyd R.N., Reid S.M., Lanigan A., Wolfe R., Reddihough D., Graham H.K. Hip displacement in cerebral palsy. J. Bone Joint Surg. Am., 2006, vol. 88, no. 1, pp. 121-129. DOI: 10.2106/JBJS.E.00071.

3. Terjesen T. Development of the hip joints in unoperated children with cerebral palsy: a radiographic study of 76 patients. Acta Orthop., 2006 , vol. 77, no. 1, pp. 125-131. DOI: 10.1080/17453670610045803.

4. Jung N.H., Pereira B., Nehring I., Brix O., Bernius P., Schroeder S.A., Kluger G.J., Koehler T., Beyerlein A., Weir S., von Kries R., Narayanan U.G., Berweck S., Mall V. Does hip displacement influence health-related quality of life in children with cerebral palsy? Dev. Neurorehabil., 2014, vol. 17, no. 6, pp. 420-425. DOI: 10.3109/17518423.2014.941116.

5. Scrutton D., Baird G. Surveillance measures of the hips of children with bilateral cerebral palsy. Arch. Dis. Child., 1997, vol. 76, no. 4, pp. 381-384. DOI: $10.1136 /$ adc.76.4.381.

6. Cooperman D.R., Bartucci E., Dietrick E., Millar E.A. Hip dislocation in spastic cerebral palsy: long-term consequences. J. Pediatr. Orthop., 1987, vol. 7, no. 3, pp. 268-276. DOI: 10.1097/01241398-198705000-00005.

7. Root L. Surgical treatment for hip pain in the adult cerebral palsy patient. Dev. Med. Child. Neurol., 2009, vol. 51, no. Suppl. 4, pp. 84-91. DOI: 10.1111/j.1469-8749.2009.03421.x.

8. De Souza R.C., Mansano M.V., Bovo M., Yamada H.H., Rancan D.R., Fucs P.M., Svartman C., de Assumpção R.M. Hip salvage surgery in cerebral palsy cases: a systematic review. Rev. Bras. Ortop., 2015, vol. 50, no. 3, pp. 254-259. DOI: 10.1016/j.rboe.2015.06.003.

9. Larnert P., Risto O., Hägglund G., Wagner P. Hip displacement in relation to age and gross motor function in children with cerebral palsy. J. Child. Orthop., 2014, vol. 8, no. 2, pp. 129-134. DOI: 10.1007/s11832-014-0570-7.

10. Reimers J. The stability of the hip in children. A radiological study of the results of muscle surgery in cerebral palsy. Acta Orthop. Scand. Suppl., 1980, vol. 184, pp. 1-100. DOI: 10.3109/ort.1980.51.suppl-184.01.

11. Connelly A., Flett P., Graham H.K., Oates J. Hip surveillance in Tasmanian children with cerebral palsy. J. Paediatr. Child. Health, 2009, vol. 45, no. 7-8, pp. 437-443. DOI: 10.1111/j.1440-1754.2009.01534.x.

12. Hägglund G., Lauge-Pedersen H., Wagner P. Characteristics of children with hip displacement in cerebral palsy. BMC Musculoskelet. Disord., 2007, vol. 8, pp. 101. DOI: 10.1186/1471-2474-8-101.

13. Terjesen T. The natural history of hip development in cerebral palsy. Dev. Med. Child. Neurol., 2012, vol. 54, no. 10, pp. 951-957. DOI: 10.1111/j.14698749.2012.04385.x.

14. Cornell M.S., Hatrick N.C., Boyd R., Baird G., Spencer J.D. The hip in children with cerebral palsy. Predicting the outcome of soft tissue surgery. Clin. Orthop. Relat. Res., 1997, no. 340, pp. 165-170. DOI: 10.1097/00003086-199707000-00021.

15. Cooke P.H., Cole W.G., Carey R.P. Dislocation of the hip in cerebral palsy. Natural history and predictability. J. Bone Joint Surg. Br., 1989, vol. 71, no. 3, pp. 441-446. DOI: 10.1302/0301-620X.71B3.2722938.

16. Hägglund G., Andersson S., Düppe H., Lauge-Pedersen H., Nordmark E., Westbom L. Prevention of dislocation of the hip in children with cerebral palsy. The first ten years of a population-based prevention programme. J. Bone Joint Surg. Br., 2005, vol. 87, no. 1, pp. 95-101.

17. Carr C., Gage J.R. The fate of nonoperated hip in cerebral palsy. J. Pediatr. Orthop., 1987, vol. 7, no. 3, pp. 262-267. DOI: 10.1097/01241398198705000-00004.

18. Miller F. Cerebral Palsy. New York: Springer-Verlag, 2005. DOI: 10.1007/b138647.

19. Sadofeva V.I., Umnov V.V., Danilova N.A. Formirovanie tazobedrennykh sustavov u bolnykh tserebralnym paralichom [Formation of the hips in patients with cerebral palsy]. Ortopediia, Travmatologiia i Protezirovanie, 1989, no. 8, pp. 29-31. (in Russian)

20. Chougule S., Dabis J., Petrie A., Daly K., Gelfer Y. Is head-shaft angle a valuable continuous risk factor for hip migration in cerebral palsy? J. Child. Orthop., 2016, vol. 10, no. 6, pp. 651-656. DOI: 10.1007/s11832-016-0774-0.

21. Heimkes B., Stotz S., Heid T. Pathogenese und Prävention der spastischen Hüftluxation [Pathogenesis and prevention of spastic hip dislocation]. Z. Orthop. Ihre Grenzgeb., 1992, vol. 130, no. 5, pp. 413-418. (in German) DOI: 10.1055/s-2008-1039644.

22. Hägglund G., Lauge-Pedersen H., Persson M. Radiographic threshold values for hip screening in cerebral palsy. J. Child. Orthop., 2007, vol. 1, no. 1, pp. 43-47. DOI: 10.1007/s11832-007-0012-x.

23. Rang M., Silver R., de la Garza J. Cerebral palsy. In: Lovell W.W., Winter R.B., eds. Pediatric orthopaedics. $2^{\text {nd }}$ Ed. Philadelphia: JB Lippincott Co. 1986. P. 345-396.

24. Vidal J., Deguillaume P., Vidal M. The anatomy of the dysplastic hip in cerebral palsy related to prognosis and treatment. Int. Orthop., 1985, vol. 9, no. 2, pp. 105-110. DOI: 10.1007/BF00266951.

25. Pountney T., Green E.M. Hip dislocation in cerebral palsy. BMJ, 2006, vol. 332, no. 7544, pp. 772-775. DOI: 10.1136/bmj.332.7544.772.

26. Chung C.Y., Park M.S., Choi I.H., Cho T.J., Yoo W.J., Lee K.M. Morphometric analysis of acetabular dysplasia in cerebral palsy. J. Bone Joint Surg. Br., 2006, vol. 88, no. 2, pp. 243-247. DOI: 10.1302/0301-620X.88B2.16274.

27. Gose S., Sakai T., Shibata T., Murase T., Yoshikawa H., Sugamoto K. Morphometric analysis of the femur in cerebral palsy: 3-dimensional CT study. J. Pediatr. Orthop., 2010, vol. 30, no. 6, pp. 568-574. DOI: 10.1097/BPO.0b013e3181e4f38d.

28. Gose S., Sakai T., Shibata T., Murase T., Yoshikawa H., Sugamoto K. Morphometric analysis of acetabular dysplasia in cerebral palsy: threedimensional CT study. J. Pediatr Orthop., 2009, vol. 29, no. 8, pp. 896-902. DOI: 10.1097/BPO.0b013e3181c0e957.

29. Khouri N. La hanche de l'enfant et de l'adolescent infirme moteur d'origine cérébrale [The hip of a child and adolescent with cerebral palsy]. Cahier d'Enseignement de la SOFCOT: Conférences d'Enseignement. Paris, Elsevier, 2001, vol. 78, pp. 123-136. (in French)

30. Knapp D.R. Jr, Cortes H. Untreated hip dislocation in cerebral palsy. J. Pediatr. Orthop., 2002, vol. 22, no. 5, pp. 668-671.

31. Khrypov S.V., Umnov V.V., Krasavina D.A., Veselov A.G., Pakhomova M.A. Khirurgicheskoe lechenie s ispolzovaniem metoda totalnogo endoprotezirovaniia tazobedrennogo sustava $\mathrm{v}$ sisteme reabilitatsii detei podrostkovogo vozrasta, stradaiushchikh detskim tserebralnym paralichom 
(DTsP) [Surgical treatment using the method of total hip replacement in the system of rehabilitation of adolescents with cerebral palsy (CP)]. Genij Ortopedii, 2017, vol. 23, no. 4, pp. 423-428.

32. Hodgkinson I., Jindrich M.L., Duhaut P., Vadot J.P., Metton G., Bérard C. Hip pain in 234 non-ambulatory adolescents and young adults with cerebral palsy: a cross-sectional multicentre study. Dev. Med. Child. Neurol., 2001, vol. 43, no. 12, pp. 806-808. DOI: 10.1017/s0012162201001463.

33. Jóźwiak M., Walczak M., Idzior M. Wystepowanie dolegliwości bólowych stawów biodrowych u chorych z mózgowym porazeniem dzieciecym [Appearance of spastic hip pain in cerebral palsy children]. Chir. Narzadow Ruchu Ortop. Pol., 2005, vol. 70, no. 2, pp. 101-104. (in Polish)

34. Van Riet A., Moens P. The McHale procedure in the treatment of the painful chronically dislocated hip in adolescents and adults with cerebral palsy. Acta Orthop. Belg., 2009, vol. 75, no. 2, pp. 181-188.

35. Moreau M., Drummond D.S., Rogala E., Ashworth A., Porter T. Natural history of the dislocated hip in spastic cerebral palsy. Dev. Med. Child. Neurol., 1979, vol. 21, no. 6, pp. 749-753. DOI: 10.1111/j.1469-8749.1979.tb01696.x.

36. Gough M. Continuous postural management and the prevention of the deformity in children with cerebral palsy: an appraisal. Dev. Med. Child. Neurol., 2009, vol. 51, no. 2, pp. 105-110. DOI: 10.1111/j.1469-8749.2008.03160.x.

37. Macias-Merlo L., Bagur-Calafat C., Girabent-Farrés M., Stuberg W.A. Effects of the standing program with hip abduction on hip acetabular development in children with spastic diplegia cerebral palsy. Disabil. Rehabil., 2016, vol. 38, no. 11, pp. 1075-1081. DOI: 10.3109/09638288.2015.1100221.

38. Ozturk M., Oktem F., Kisioglu N., Demirci M., Altuntas I., Kutluhan S., Dogan M. Bladder and bowel control in children with cerebral palsy: casecontrol study. Croat. Med. J., 2006, vol. 47, no. 2, pp. 264-270.

39. Campanozzi A., Capano G., Miele E., Romano A., Scuccimarra G., Del Giudice E., Strisciuglio C., Militerni R., Staiano A. Impact of malnutrition on gastrointestinal disorders and gross motor abilities in children with cerebral palsy. Brain Dev., 2007, vol. 29, no. 1, pp. 25-29. DOI: 10.1016/j. braindev.2006.05.008.

40. Reddihough D. Cerebral palsy in childhood. Aust. Fam. Physician, 2011, vol. 40, no. 4, pp. 192-196.

41. Duruflé-Tapin A., Colin A., Nicolas B., Lebreton C., Dauvergne F., Gallien P. Analysis of the medical causes of death in cerebral palsy. Ann. Phys. Rehabil. Med., 2014, vol. 57, no. 1, pp. 24-37. DOI: 10.1016/j.rehab.2013.11.002.

42. Uddenfeldt Wort U., Nordmark E., Wagner P., Düppe H., Westbom L. Fractures in children with cerebral palsy: a total population study. Dev. Med. Child. Neurol., 2013, vol. 55, no. 9, pp. 821-826. DOI: 10.1111/dmcn.12178.

43. Fulford G.E. Surgical management of ankle and foot deformities in cerebral palsy. Clin. Orthop. Relat. Res., 1990, no. 253, pp. 55-61.

44. Lebarbier P., Penneçot G.F. L'infirmité motrice d'origine cérébrale (IMOC) [Cerebral palsy]. Rev. Chir. Orthop., 2006, vol. 92, no. 4, pp. 393-395. (in French) DOI: 10.1016/S0035-1040(06)75782-8.

45. Horstmann H.M., Hosalkar H., Keenan M.A. Orthopaedic issues in the musculoskeletal care of adults with cerebral palsy. Dev. Med. Child. Neurol., 2009, vol. 51, no. Suppl. 4, pp. 99-105. DOI: 10.1111/j.1469-8749.2009.03417.x.

46. Chagas P.S.C., Drumond C.M., Toledo A.M., de Campos A.C., Camargos A.C.R., Longo E., Leite H.R., Ayupe K.M.A., Moreira R.S., Morais R.L.S., Palisano R.J., Rosenbaum P.; PartiCipa Brazil Research Group. Study protocol: functioning curves and trajectories for children and adolescents with cerebral palsy in Brazil - PartiCipa Brazil. BMC Pediatr., 2020, vol. 20, no. 1, pp. 393. DOI: 10.1186/s12887-020-02279-3.

47. Bagg M.R., Farber J., Miller F. Long-term follow-up of hip subluxation in cerebral palsy patients. J. Pediatr. Orthop., 1993, vol. 13 , no. 1, pp. $32-36$. DOI: 10.1097/01241398-199301000-00007.

48. Gudjonsdottir B., Mercer V.S. Hip and spine in children with cerebral palsy: musculoskeletal development and clinical implications. Pediatr. Phys. Ther., 1997, vol. 9, pp. 179-185.

49. Dobson F., Boyd R., Parrott J., Nattrass G.R., Graham H.K. Hip surveillance in children with cerebral palsy. Impact on the surgical management of spastic hip disease. J. Bone Joint Surg. Br., 2002, vol. 84, no. 5, pp. 720-726. DOI: 10.1302/0301-620x.84b5.12398.

50. Kalen V., Bleck E.E. Prevention of spastic paralytic dislocation of the hip. Dev. Med. Child. Neurol., 1985, vol. 27, no. 1, pp. 17-24. DOI: 10.1111/ j.1469-8749.1985.tb04520.x.

51. Clarke A.M., Redden J.F. Management of hip posture in cerebral palsy. J. R. Soc. Med., 1992, vol. 85, no. 3, pp. 150-151.

52. Reidy K., Heidt C., Dierauer S., Huber H. A balanced approach for stable hips in children with cerebral palsy: a combination of moderate VDRO and pelvic osteotomy. J. Child. Orthop., 2016, vol. 10, no. 4, pp. 281-288. DOI: 10.1007/s11832-016-0753-5.

53. Popkov D., Journeau P., Popkov A. Comparative study on results of reconstructive surgery in 45 hip joints of 25 children with cerebral palsy. Eur. Orthop. Traumatol., 2014, vol. 5, pp. 57-63. DOI: 10.1007/s12570-013-0201-7.

54. Elkamil A.I., Andersen G.L., Hägglund G., Lamvik T., Skranes J., Vik T. Prevalence of hip dislocation among children with cerebral palsy in regions with and without a surveillance programme: a cross sectional study in Sweden and Norway. BMC Musculoskelet. Disord., 2011, vol. 12 , pp. 284. DOI: $10.1186 / 1471-2474-12-284$.

55. Krebs A., Strobl W.M., Grill F. Neurogenic hip dislocation in cerebral palsy: quality of life and results after hip reconstruction. J. Child. Orthop., 2008, vol. 2, no. 2, pp. 125-131. DOI: 10.1007/s11832-008-0080-6.

56. Stott N.S., Piedrahita L.; AACPDM. Effects of surgical adductor releases for hip subluxation in cerebral palsy: an AACPDM evidence report. Dev. Med. Child. Neurol., 2004, vol. 46, no. 9, pp. 628-645. DOI: 10.1017/s0012162204001069.

57. Schmale G.A., Eilert R.E., Chang F., Seidel K. High reoperation rates after early treatment of the subluxating hip in children with spastic cerebral palsy. J. Pediatr. Orthop., 2006, vol. 26, no. 5, pp. 617-623. DOI: 10.1097/01.bpo.0000235391.26666.b0.

58. McNerney N.P., Mubarak S.J., Wenger D.S. One-stage correction of the dysplastic hip in cerebral palsy with the San Diego acetabuloplasty: results and complications in 104 hips. J. Pediatr. Orthop., 2000, vol. 20, no. 1, pp. 93-103.

59. Jóźwiak M., Marciniak W., Piontek T., Pietrzak S. Dega's transiliac osteotomy in the treatment of spastic hip subluxation and dislocation in cerebral palsy. J. Pediatr. Orthop., 2000, vol. 9, no. 4, pp. 257-264. DOI: 10.1097/01202412-200010000-00009.

60. Karlen J.W., Skaggs D.L., Ramachandran M., Kay R.M. The Dega osteotomy: a versatile osteotomy in the treatment of developmental and neuromuscular hip pathology. J. Pediatr. Orthop., 2009, vol. 29, no. 7, pp. 676-682. DOI: 10.1097/BPO.0b013e3181b7691a.

61. Reichel H., Hein W. Dega acetabuloplasty combined with intertrochanteric osteotomies. Clin. Orthop. Relat. Res., 1996, no. 323, pp. $234-242$. DOI: 10.1097/00003086-199602000-00032.

62. Sankar W.N., Spiegel D.A., Gregg J.R., Sennett B.J. Long-term follow-up after one-stage reconstruction of dislocated hips in patients with cerebral palsy. J. Pediatr. Orthop., 2006, vol. 26, no. 1, pp. 1-7. DOI: 10.1097/01.bpo.0000190842.77036.d0.

63. Tomov A.D., Diachkov K.A., Popkov D.A. Kliniko-rentgenologicheskie rezultaty mnogourovnevykh operativnykh vmeshatelstv pri podvyvikhe i vyvikhe bedra u detei s DTsP [Clinical and radiographic results of multilevel surgical interventions for hip subluxation and dislocation in children with cerebral palsy]. Genij Ortopedii, 2018, vol. 24, no. 1, pp. 24-32.

64. Tomov A.D., Diachkov K.A., Popkov D.A. Parametry rentgenovskoi koksometrii pri vypolnenii rekonstruktivnykh operatsii na tazobedrennom sustave v ramkakh mnogourovnevykh operativnykh vmeshatelstv u detei s DTsP [Parameters of radiographic coxometry in reconstructive operations on the hip joint as part of multilevel surgical interventions in children with cerebral palsy]. Genij Ortopedii, 2019, vol. 25, no. 3, pp. 337-347.

65. Park H., Abdel-Baki S.W., Park K.B., Park B.K., Rhee I., Hong S.P., Kim H.W. Outcome of Femoral Varus Derotational Osteotomy for the Spastic Hip Displacement: Implication for the Indication of Concomitant Pelvic Osteotomy. J. Clin. Med., 2020, vol. 9, no. 1, pp. 256. DOI: 10.3390/ jcm9010256.

66. Chung C.Y., Choi I.H., Cho T.J., Yoo W.J., Lee S.H., Park M.S. Morphometric changes in the acetabulum after Dega osteotomy in patients with cerebral palsy. J. Bone Joint Surg. Br., 2008, vol. 90, no. 1, pp. 88-91. DOI: 10.1302/0301-620X.90B1.19674.

67. Buckley S.L., Sponseller P.D., Magid D. The acetabulum in congenital and neuromuscular hip instability. J. Pediatr. Orthop., 1991, vol. 11, no. 4, pp. 498-501. DOI: 10.1097/01241398-199107000-00015.

68. Kim H.T., Wenger D.R. Location of acetabular deficiency and associated hip dislocation in neuromuscular hip dysplasia: three-dimensional computed tomographic analysis. J. Pediatr. Orthop., 1997, vol. 17, no. 2, pp. 143-151. DOI: 10.1097/00004694-199703000-00002.

69. Mary P. Déformations acétabulaires - Comment les analyser? [Acetabular deformities - How to analyze them?]. Les déformations des members 
inférieurs “de la consultation à l'acte opératoire”. Monographie du groupe d'étude en orthopédie pédiatrique sous la direction de P. Lascombes et P. Journeau. [Deformities of the lower limbs "from consultation to surgery". Monograph of the pediatric orthopedics study group under the direction of P. Lascombes et P. Journeau.]. Montpellier: Sauramps Médical. 2009. P. 101-108. (in French)

70. Tomov A.D., Diachkov K.A., Popkov D.A. Sposob atsetabuloplastiki u detei s tserebralnym paralichom [A technique of acetabuloplasty in children with cerebral palsy]. Patent RF no. 2689032, A 61 B 17/56, 2019. (in Russian)

71. Park M.S., Chung C.Y., Lee S.H., Cho T.J., Yoo W.J., Choi I.H. Two-dimensional computed tomographic measurement of acetabulum - reliability, validity, and limitation. J. Pediatr. Orthop., 2008, vol. 28, no. 8, pp. 812-818. DOI: 10.1097/BPO.0b013e31818af6c9.

72. Gicquel P., Stanchina C., Schneider L., Giacomelli M.C., Karger C., Clavert J.M. Technique d'ostéotomie fémorale proximale par plaque LCP Synthès [Proximal femoral osteotomy technique using LCP Synthès]. Les déformations des members inférieurs "de la consultation à l'acte opératoire". Monographie du groupe d'étude en orthopédie pédiatrique sous la direction de P. Lascombes et P. Journeau [Deformities of the lower limbs "from consultation to surgery". Monograph of the pediatric orthopedics study group under the direction of P. Lascombes et P. Journeau]. Montpellier: Sauramps Médical. 2009. P. 121-124. (in French)

73. Beauchesne R., Miller F., Moseley C. Proximal femoral osteotomy using the AO fixed-angle blade plate. J. Pediatr. Orthop., 1992, vol. 12, no. 6, pp. $735-740$.

74. Hau R., Dickens D.R., Nattrass G.R., O'Sullivan M., Torode I.P., Graham H.K. Which implant for proximal femoral osteotomy in children? A comparison of the AO (ASIF) 90 degree fixed-angle blade plate and the Richards intermediate hip screw. J. Pediatr. Orthop., 2000, vol. 20, no. 3, pp. 336-343.

75. Mazur J.M., Danko A.M., Standard S.C., Loveless E.A., Cummings R.J. Remodeling of the proximal femur after varus osteotomy in children with cerebral palsy. Dev. Med. Child. Neurol., 2004, vol. 46, no. 6, pp. 412-415. DOI: 10.1017/s0012162204000660.

76. Mallet C., Ilharreborde B., Presedo A., Khairouni A., Mazda K., Penneçot G.F. One-stage hip reconstruction in children with cerebral palsy: longterm results at skeletal maturity. J. Child. Orthop., 2014, vol. 8, no. 3, pp. 221-228. DOI: 10.1007/s11832-014-0589-9.

77. Rutz E., Brunner R. The pediatric LCP hip plate for fixation of proximal femoral osteotomy in cerebral palsy and severe osteoporosis. J. Pediatr. Orthop., 2010, vol. 30, no. 7, pp. 726-731. DOI: 10.1097/BPO.0b013e3181efb86b.

78. Bayusentono S., Choi Y., Chung C.Y., Kwon S.S., Lee K.M., Park M.S. Recurrence of hip instability after reconstructive surgery in patients with cerebral palsy. J. Bone Joint Surg. Am., 2014, vol. 96, no. 18, pp. 1527-1534. DOI: 10.2106/JBJS.M.01000.

79. Popkov D., editor. Understanding in Children with Cerebral Palsy: Orthopedic Problems. New York, NOVA Science Publishers. 2020.

80. Rutz E., Vavken P., Camathias C., Haase C., Jünemann S., Brunner R. Long-term results and outcome predictors in one-stage hip reconstruction in children with cerebral palsy. J. Bone Joint Surg. Am., 2015, vol. 97, no. 6, pp. 500-506. DOI: 10.2106/JBJS.N.00676.

81. McGinley J.L., Dobson F., Ganeshalingam R., Shore B.J., Rutz E., Graham H.K. Single-event multilevel surgery for children with cerebral palsy: a systematic review. Dev. Med. Child. Neurol., 2012, vol. 54, no. 2, pp. 117-128. DOI: 10.1111/j.1469-8749.2011.04143.x.

82. Miller F., Dias R.C., Dabney K.W., Lipton G.E., Triana M. Soft-tissue release for spastic hip subluxation in cerebral palsy. J. Pediatr. Orthop., 1997, vol. 17, no. 5, pp. 571-584. DOI: 10.1097/00004694-199709000-00003.

83. Gordon J.E., Parry S.A., Capelli A.M., Schoenecker P.L. The effect of unilateral varus rotational osteotomy with or without pelvic osteotomy on the contralateral hip in patients with perinatal static encephalopathy. J. Pediatr. Orthop., 1998, vol. 18, no. 6, pp. 734-737.

84. Settecerri J.J., Karol L.A. Effectiveness of femoral varus osteotomy in patients with cerebral palsy. J. Pediatr. Orthop., 2000, vol. 20, no. 6, pp. 776780. DOI: 10.1097/00004694-200011000-00015.

85. Noonan K.J., Walker T.L., Kayes K.J., Feinberg J. Effect of surgery on the nontreated hip in severe cerebral palsy. J. Pediatr. Orthop., 2000, vol. 20, no. 6, pp. 771-775. DOI: 10.1097/00004694-200011000-00014.

86. Canavese F., Emara K., Sembrano J.N., Bialik V., Aiona M.D., Sussman M.D. Varus derotation osteotomy for the treatment of hip subluxation and dislocation in GMFCS level III to V patients with unilateral hip involvement. Follow-up at skeletal maturity. J. Pediatr Orthop., 2010, vol. 30, no. 4, pp. 357-364. DOI: 10.1097/BPO.0b013e3181d8fbc1.

87. Owers K.L., Pyman J., Gargan M.F., Witherow P.J., Portinaro N.M. Bilateral hip surgery in severe cerebral palsy: a preliminary review. J. Bone Joint Surg. Br., 2001, vol. 83, no. 8, pp. 1161-1167. DOI: 10.1302/0301-620x.83b8.11266.

88. Larsson M., Hägglund G., Wagner P. Unilateral varus osteotomy of the proximal femur in children with cerebral palsy: a five-year follow-up of the development of both hips. J. Child. Orthop., 2012, vol. 6, no. 2, pp. 145-151. DOI: 10.1007/s11832-012-0401-7.

89. Dhawale A.A., Karatas A.F., Holmes L., Rogers K.J., Dabney K.W., Miller F. Long-term outcome of reconstruction of the hip in young children with cerebral palsy. Bone Joint J., 2013, vol. 95-B, no. 2, pp. 259-265. DOI: 10.1302/0301-620X.95B2.30374.

90. Mubarak S.J., Valencia F.G., Wenger D.R. One-stage correction of the spastic dislocated hip. Use of pericapsular acetabuloplasty to improve coverage. J. Bone Joint Surg. Am., 1992, vol. 74, no. 9, pp. 1347-1357.

91. Stasikelis P.J., Davids J.R., Johnson B.H., Jacobs J.M. Rehabilitation after femoral osteotomy in cerebral palsy. J. Pediatr. Orthop., 2003, vol. 12, no. 5, pp. 311-314. DOI: 10.1097/01.bpb.0000078260.58527.aa.

Received: 18.05.2021

\section{Information about the authors:}

1. Dmitry A. Popkov, M.D., Ph.D., Professor of RAS, correspondent member French Academy of Medical Sciences, Ilizarov National Medical Research Centre for Traumatology and Orthopedics, Kurgan, Russian Federation, ORCID: 0000-0002-8996-867X,

Email: dpopkov@mail.ru

2. Georgy M. Chibirov, M.D., Ph.D.,

Ilizarov National Medical Research Centre for Traumatology and Orthopedics, Kurgan, Russian Federation,

Email: georgii_chibirov@mail.ru

3. Ahmed D. Tomov, M.D.,

Morozov Children's City Clinical Hospital of the Moscow City Health Department, Moscow, Russian Federation 